\title{
HAK KEWARISAN ZAWIL ARHAM (PERSPEKTIF MAZHAB HANAFIYAH DAN SYAFI'TYAH)
}

\author{
Sitti Suryani, Nurul Husna dan Sofia Adela \\ (Fakultas Syariah IAIN Langsa)
}

\begin{abstract}
In this life, humans have their own property in their lifetime, but after the man passes away, the property will belong to his heirs. The jurists agree that ashabul Furud is prioritized in taking inheritance, if there is a remnant, it is given for heirs of asabah. The jurists also agree that if someone dies and has the heirs of ashabul furudh or asabah, the relatives of the zawil arham will not have right to inherit. They have differents arguments about who will has the right to inherit, if the heir does not leave ashabul furudh or ashabah relatives. The Hanafiyah School argues that the zawil arham group has the right to inherit, if the heir does not leave ashabul furudh relatives and asabah. On the other hand, the Syafi'iyah school argues that the zawil arham group does not have right to inherit, but the property should be given to the Baitul Mal. The results of the study concluded that according to the Hanafiyah School, zawil arham is more rightful to get inheritance than others, because they have a kinship relationship with the heir, and they are more prioritized than baitul mall. Otherwise, the school of Syafi'yah stated that zawil arham does not have right to inherit the property from the heir because zawil arham is not classified as relatives of ashabul furudh or asabah, so that the property must be handed to baitul mal. The Legal terms used by the Hanafiyah school is based on the Koran in Surah al-Anfal (75), and hadith. Meanwhile, the Shafi'iyah school is based on Surah maryam (64), and hadith.

Keywords: Zawil Arham, Ashabah, Ashabul Furudh, School
\end{abstract}

Abstrak: Dalam kehidupan ini manusia disaat hidupnya memiliki harta dan harta tersebut milik mereka masing-masing. Tetapi setelah manusia itu meninggal dunia, maka harta tersebut menjadi milik ahli warisnya. Para fuqaha sepakat bahwa ashabul furudh didahulukan dalam mengambil harta warisan, jika ada sisa maka untuk ahli waris ashabah. Para fuqaha juga sepakat jika pewaris meninggal, meninggalkan ahli waris ashabul furudh ataupun ashabah maka kerabat zawil arham tidak berhak mendapat warisan. Mereka berbeda pendapat tentang siapa yang berhak menerima harta warisan jika pewaris tidak meninggalkan kerabat ashabul furudh ataupun ashabah . Mazhab Hanafiyah berpendapat bahwasanya golongan zawil arham berhak mendapatkan harta warisan, apabila pewaris tidak meninggalkan kerabat ashabul furudh dan juga ashabah. Sedangkan mazhab Syafi'iyah berpendapat golongan zawil arham tidak berhak atas harta warisan itu sendiri, tetapi harta tersebut kembali kepada baitul mal. Adapun hasil dari penelitian menyimpulkan, bahwa mazhab Hanafiyah zawil arham lebih berhak menerima harta warisan dari pada yang lain, sebab mereka mempunyai hubungan kerabat dengan pewaris, dan mereka didahulukan dari pada baitul mal. Sedangkan mazhab Syafi'yah berpendapat bahwa zawil arham tidak berhak mendapatkan 
harta warisan dari pewaris dengan alasan bahwa zawil arham bukan termasuk kerabat ashabul furudh ataupun ashabah, tetapi harta tersebut diserahkan ke baitul mal. Istinbat hukum yang digunakan mazhab Hanafiyah berdasarkan Alquran dalam surat al-Anfal (75), dan hadis. Sedangkan mazhab Syafi'iyah berdalil berdasarkan surat maryam (64), dan hadis.

Kata Kunci: Zawil Arham, Ashabah, Ashabul Furudh, Mazhab

\section{PENDAHULUAN}

Hukum Islam merupakan hukum yang bersumber dari Alquran dan hadis yang mengatur segala perbuatan hukum bagi masyarakat yang menganut agama Islam. Hukum Islam adalah hukum Allah, dan sebagai hukum Allah, ia menuntut kepatuhan dari umat Islam untuk melaksanakannya sebagai kelanjutan dari keimanannya terhadap Allah SWT. Keimanan akan wujud Allah menuntut kepercayaan akan segala sifat dan kudrat Allah. Aturan Allah tentang tingkah laku manusia itu sendiri merupakan satu bentuk dari Iradat Allah dan karena itu kepatuhan menjalankan aturan Allah merupakan perwujudan dari iman kepada Allah. Diantara hubungan yang mengatur hubungan sesama manusia yang ditetapkan Allah adalah aturan tentang hukum mawarits. Mawarits merupakan salah satu bagian dari ilmu fiqh. Fiqh ialah ilmu tentang hukumhukum syari'at 'amaliyah yang diambil dari dalil-dalil terperinci. ${ }^{48}$ Fiqh terbagi pada bidang ibadah dan bidang mu'amalah, salah satu bagian dari bidang mu'amalah adalah mawarits, yaitu hukum yang mengatur tentang pembagian harta warisan.

Ilmu mawarits adalah sekumpulan kaidah dan hukum-hukum yang disyariatkan Allah dan dijelaskan

\footnotetext{
${ }^{48}$ Amir Syarifuddin, Ushul Fiqh, Jilid I,
} (Jakarta: Kencana, 2008), hal. 3. oleh Rasulullah yang dengannya diketahui siapa yang berhak menerima warisan dan bagiannya masingmasing. ${ }^{49}$ Hukum kewarisan Islam adalah hukum yang mengatur segala sesuatu yang berkenaan dengan peralihan hak atau kewajiban atas harta kekayaan seseorang setelah ia meninggal dunia kepada ahli warisnya. Dengan demikian, dalam hukum kewarisan ada tiga unsur pokok yang saling terkait yaitu pewaris, harta peninggalan, dan ahli waris. ${ }^{50}$

Kewarisan tidak akan terjadi bila tidak ada orang yang meninggal dunia. Peristiwa kematian akan mengakibatkan munculnya problematika kewarisan dan menghendaki adanya ketentuan hukum mengenai kewarisan. Kematian merupakan peristiwa hukum, tidak hanya kepada orang yang akan menajadi ahli waris, tetapi juga kepada harta yang ditinggalkan oleh si pewaris.

Warisan dapat diperoleh dengan sebab nasab atau kerabat terdiri dari ashabul furudh, ashabah, dan zawil arham. ashabul furudh yaitu ahli waris yang mempunyai bagian tertentu dalam hal pusaka mempusakai, dimana Allah SWT telah menjelaskan

\footnotetext{
${ }^{49}$ Muhammad Suhaili Sufyan, Fiqh Mawaris Praktis, (Bandung: Citapustaka Media Perintis, 2012), hal. 2.

${ }^{50}$ Ali Parman, Kewarisan Dalam AlQur'an, (Jakarta: Raja Grafindo Persada, 1995), hal. 1.
}

133 | Hak Kewarisan Zawil Arham (Perspektif Mazhab Hanafiyah Dan Syafi'iyah) 
sejelas-jelasnya dalam ayat mawaris. ${ }^{51}$

Sedangkan ashabah yaitu ahli waris yang menguasai harta waris karena ia menjadi ahli waris tunggal. Selain itu ia juga menerima seluruh sisa harta warisan setelah para ahli waris ashabul furudh mengambil ketentuan mereka jika terdapat sisa, dan mereka mengambil semua harta jika tidak ada ahli waris ashabul furudh. ${ }^{52}$ Adapun zawil arham yaitu setiap kerabat yang tidak tergolong ashabul furudh dan tidak pula ashabah. Adapun lafazh zawil arham yang dimaksud dalam istilah fuqaha adalah kerabat pewaris yang tidak mempunyai bagian atau hak waris tertentu, baik dalam Alquran ataupun hadis, bukan pula termasuk dari para ashabul furudh dan ashabah, misalnya: bibi (saudara perempuan ayah atau ibu), paman (saudara laki-laki ibu), keponakan laki-laki dari saudara perempuan, cucu laki-laki dari anak perempuan, dan sebagainya. ${ }^{53}$ Fuqaha ulama pun menyepakati akan hal tersebut.

Para ulama sepakat bahwa zawil arham tidak mendapatkan harta warisan apabila seseorang meninggal dunia meninggalkan ahli waris ashabul furudh atau ashabah. Tetapi para ulama berselisih pendapat tentang posisi zawil arham mendapatkan hak kewarisan sebagai ahli waris apabila pewaris tidak meninggalkan ahli waris

${ }^{51}$ Fatchur Rahman, Ilmu Waris, (Bandung: PT.Alma'arif, 1971), h. 482.

${ }^{52}$ Beni Ahmad Saebani, Fiqh Mawaris, (Bandung: Pustaka Setia, 2006), hal. 156.

${ }^{53}$ Muhammad Ali Ash-Syabuni, Pembagian Waris Menurut Islam, Terj: A. M. Basalamah, (Jakarta: Gema Insani Press, 2007), hal.144. ashabul furudh atau ashabah. ${ }^{54}$ Mazhab Syafi'iyah berpendapat bahwa kerabat yang tergolong dalam zawil arham tidak berhak mendapatkan harta warisan. Bila seseorang meninggal dan hanya memiliki kerabat yang tergolong zawil arham, tidak ada seorang pun ahli waris ashabul furudh tidak pula ashabah maka harta warisan diberikan kepada Baitul Mal. ${ }^{55}$ Tetapi ada beberapa murid beliau seperti Imam Al-Muzani, Ibnu Suraij dan Imam An-Nawawi, mereka menyatakan bahwa bila pewaris tidak meninggalkan ahli waris ashabul furudh tidak pula ashabah maka harta warisan diberikan kepada kerabat zawil arham.56 Mazhab Hanafiyah berpendapat bahwa zawil arham berhak mendapatkan harta warisan bila pewaris tidak meninggalkan ahli waris ashabul furudh ataupun ashabah. ${ }^{57}$

\section{PENDAPAT MAZHAB HANAFIYAH DAN SYAFI'TYAH TENTANG HAK KEWARISAN ZAWIL ARHAM}

\section{Pendapat Mazhab Hanafiyah}

Adapun pengertian zawil arham yang disebutkan dalam Kitab Takhmilah Al-Bahru ArRaiq karangan ath-Thuri Al-Qadiri al-Hanafi, bahwa:

54 Wahbah Az-Zuhaili, Fiqh Islam Wa Adillatuhu, Jilid XI, Terj: Abdul Hayyie aKattani, dkk, (Jakarta: Gema Insani, 2007), hal. 346 .

${ }^{55}$ Al-Baghawi, At-Tahzib Fi Fiqh Al-Imam Ash-Syafi'i, Jilid (Beirut: Dar al-Kutub al Ilmiyah, 1997), hal. 54-58.

${ }^{56}$ An-Nawawi, Yahya bin Syarf, Raudhahath-Thalibin, Jilid VI, (Beirut: Dar Al-Kitab Al-'Ilmiyah, 1992), hal. 7-8.

${ }^{57}$ Ath-Thuri al-Qadiri al-Hanafi, Takhmilah Al-BahruAr-Raiq, Jilid X, (Kairo: Dar Al-Kitab Al-Islami, t.t), hal. 396. 


$$
\text { وهو قريب ليس بذي سهم ولاعصبة } 58
$$

Zawil arham ialah kerabat yang tidak tergolong pemilik saham (ketentuan) dan juga bukan ashabah

Ulama fuqaha sepakat bahwa zawil arham tidak mendapat harta warisan apabila pewaris meninggalkan ahli waris ashabul furudh atau ashabah.59 Tetapi para fuqaha berbeda pendapat tentang hak kewarisan mereka, apabila pewaris tersebut tidak meninggalkan ahli waris ashabul furudh maupun ashabah. Adapun masalah hak waris zawil arham di dalam kitab Takhmilah Al-Bahru Ar-Raiq menyebutkan:

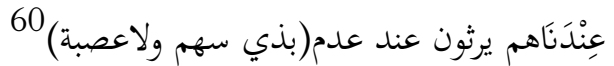

Menurut kami, mereka itu (zawil arham) dapat warisan ketika tidak ada dua ahli waris (ashabul furudh dan ashabah).

Maksud dari pendapat di atas, mazhab Hanafiyah berpendapat bahwa zawil arham mendapatkan hak warisan bila pewaris yang telah wafat tidak meninggalkan ahli waris ashabul furudh atau ahli waris ashabah. Pendapat ini merupakan jumhur sahabat, di antaranya, Umar bin Khattab, Ali bin Abi Thalib, Ibnu Abbas, Ibnu Mas'ud, Mu'adz bin Jabal, dari golongan tabi'in antara lain ialah Syuraih al-qadhi, Ibnu Sirrin, 'Atha', Mujahid, yang menyatakan bahwa zawil arham (kerabat)

${ }^{58}$ Ath-Thuri al-Qadiri al-Hanafi, Takhmilah Al-bahru Ar-Raiq, Jilid IX, (Kairo: Dar Al-Kitab Al-Islami, t.t), hal. 396.

${ }^{59}$ Wahbah Az-Zuhaili, Fiqh Islam Wa Adillatuhu, Jilid XI, Terj: Abdul Hayyie aKattani, dkk, (Jakarta: Gema Insani, 2007), hal. 451.

${ }^{60}$ Ath-Thuri al-Qadiri al-Hanafi, Takhmilah Al-bahru Ar-Raiq..., hal. 396. berhak mendapat waris, bila tidak ada ashabul furudh, ataupun ashabah yang menerima harta pewaris. ${ }^{61}$

Adapun kerabat yang tergolong dalam zawil arham, diantaranya ialah:

1. Kakek dari pihak ibu

2. Cucu dari anak perempuan

3. Anak perempuan dari saudara laki-laki kandung atau sebapak

4. Anak dari saudara perempuan kandung atau sebapak

5. Anak dari saudara laki-laki dan perempuan seibu

6. Saudara laki-laki ayah (paman) yang seibu

7. Anak perempuan dari paman kandung atau sebapak

8. Saudara perempuan ayah (bibi)

9. Saudara laki-laki ibu (paman)

10.Saudara perempuan ibu (bibi) 62

2. Pendapat Mazhab Syafi'iyah

Didalam mazhab Syafi'iyah juga terjadi perbedaan pendapat mengenai hak kewarisan zawil arham, beberapa pengikut Imam Syafi'i tidak sependapat dengan Imam Syafi'i. Menurut mazhab Syafi'iyah dalam kitab Fathul Mu'in yang menyatakan:

$$
\text { ذوو الأرحام } 63 \text { ولقد كلهم فأصل المذهب أنه لا يورث }
$$

Jika seluruh ahli waris tidak ada maka mazhab Syafi'iyah berpendapat zawil arham tidak mendapatkan warisan

Didalam at-Tahzib juga dijelaskan:

اذا مات عن مال، ولا وارث له من جهة النسب،ولا

${ }^{61}$ Fatchur Rahman, Ilmu Waris, (Bandung: Alma'arif, 1975), hal. 353.

${ }^{62}$ Al-Ghamimi, al-Hanafi, Al-Lubab, Jilid IV, (Beirut: Maktabah Al-Ilmiyah), hal. 200.

${ }^{63}$ Zainuddin al-Malibari, Fathul Mu'in, Jilid III, (Beirut: Dar Kitab Alawiyah), hal. 225.

135 | Hak Kewarisan Zawil Arham (Perspektif Mazhab Hanafiyah Dan Syafi'iyah) 


$$
\begin{aligned}
& \text { من جهة الولاء، أو كانوا أصحاب فرائض، وفضل } \\
& \text { من فرضهم- صرف إلى بيت المال، فإن كان } \\
& \text { الميت كافرا صار ماله لمصالح المسلمين فيئا، وإن } \\
& 64 \\
& \text { كان مسلما صار ماله مير اثا للمسلمين }
\end{aligned}
$$

jika seseorang meninggal dan meninggalkan harta namun ia tidak memiliki ahli waris, baik dari jalur nasab ataupun dari jalur memerdekakan budak atau ia memiliki ahli waris ashabul furudh, namun harta tersebut masih tersisa (dari pembagian ahli waris) harta tersebut dialihkan ke baitul mal. Jika si mayit merupakan orang kafir maka hartanya dijadikan sebagai fai' (untuk kemaslahatan kaum muslimin). Dan jika si mayit seorang muslim maka hartanya menjadi harta warisan bagi para muslim.

Maksud dari pendapat mazhab Syafi'iyah tersebut yaitu zawil arham tidak mendapatkan harta warisan, meskipun pewaris meninggal dunia tanpa meninggalkan ahli waris ashabul furudh ataupun ashabah, maka harta peninggalannya diserahkan kebaitul mal untuk disalurkan demi kepentingan kaum muslimin pada umumnya, dan tidak diberikan kepada zawil arham, walaupun ia meninggalkan ahli waris zawil arham. Tetapi mazhab Syafi'iyah juga mensyaratkan baitul mal tersebut harus terkelola dengan baik. Jika tidak ditemukan baitul mal maka baitul mal tersebut tidak teratur, maka harta warisan tersebut dikembalikan

${ }^{64} \mathrm{Al}$-Baqhawi, At-Tahzib Fi Fiqh Al-Imam Ash-Syafi'i, Jilid V, (Beirut: Dar al-Kutub alIlmiyah), hal. 54-58. kekerabat zawil arham. ${ }^{65}$

Pendapat ini merupakan pendapat Zaid bin Tsabit, Sa'id bin alMusayyab dan Sa'id bin Jubair. Pendapat ini juga diambil oleh alAuza'i, Abu Tsaur, Dawud, dan Ibnu Jarir ath-Thabari. 66

Adapun murid-murid Imam Syafi'i yang tidak sependapat dengan beliau diantaranya Imam Al-Muzani, Ibnu Suraij dan Imam An-Nawawi. Seperti yang dijelaskan didalam kitab Raudhah ath-Thalibin:

$$
\text { كصب الأرحام: هم كل قريب ليس بذي فرض ولا }
$$

zawil arham: mereka tiap-tiap kerabat selain zawil furudh dan selain ashabah وقال المزين وابن سريج: إن لم يخلف الميت إلا ذافرض لا يستغرق، رد الباقي عليه، إلا الزوج والزوجة، فلا رد عليهما ـ فإن لم يخلف ذافرض ولا عصبة، ورث ذوو الأرحام

Dan berkata Al-Muzani dan Ibnu Suraiz: jika si mayit tidak meninggalkan ahli waris selain seorang zawil furudh yang tidak menghabiskan harta maka sisanya dikembalikan kepadanya (radd) selain suami istri, tidak ada radd untuk kedua mereka. Jika ia tidak meninggalkan zawil furudh maupun ashabah maka diwarisi oleh zawil arham.

Demikian pula Imam Al-baqhawi $(516 \mathrm{H} / 1122 \mathrm{M})$ berpendapat bahwa kerabat zawil arham lebih berhak

${ }^{65}$ An-Nawawi, Yahya bin Syarf, Raudhah ath-Thalibin, Jilid VI, (Beirut: Dar Al-Kitab Al-'Ilmiyah, 1992), hal. 7.

${ }^{66}$ Wahbah Az-Zuhaili, Fiqh Islam Wa Adillatuhu, Jilid XI, hal. 453.

${ }^{67}$ An-Nawawi, Yahya bin Syarf, Raudhah ath-Thalibin, Jilid VI..., hal. 7.

${ }^{68}$ Ibid., hal. 8. 
mendapatkan harta warisan dari pada baitul mal. ${ }^{69}$ Ulama Syafi'iyah lainnya yang berpendapat demikian yaitu Imam Abu Hasan bin Suraiq dan Imam al-Mawardi. ${ }^{70}$

\section{Istinbath Hukum Mazhab Hanafiyah dan Syafi'iyah Tentang Hak Kewarisan Zawil Arham}

1. Metode Istinbath hukum mazhab Hanafiyah tentang hak kewarisan zawil arham.

Adapun alasan fuqaha mazhab Hanafiyah berpendapat bahwa, kerabat zawil arham berhak mendapatkan harta warisan apabila pewaris tidak meninggalkan ahli waris ashabul furudh atau ashabah ialah berdasarkan firman Allah SWT:

Dan orang-orang yang beriman sesudah itu kemudian berhijrah serta berjihad bersamamu Maka orang-orang itu Termasuk golonganmu (juga). orang-orang yang mempunyai hubungan kerabat itu sebagiannya lebih berhak terhadap sesamanya (daripada yang bukan kerabat) di dalam kitab Allah. Sesungguhnya Allah Maha mengetahui segala sesuatu. (QS. Al-Anfaal: 75) ${ }^{71}$

Adapun maksud dari ayat di atas yang telah dijelaskan didalam kitab Tafsir Al-Munir karangan Wahbah az-Zuhaili yaitu:

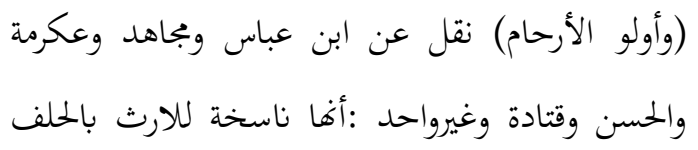

${ }^{69}$ Al-Baqhawi, At-Tahzib Fi Fiqh Al-Imam Ash-Syafi 'i, Jilid V..., hal. 59.

${ }^{70}$ An-Nawawi, Yahya bin Syarf, Raudhah ath-Thalibin, Jilid VI..., hal. 8.

${ }^{71}$ Departemen Agama RI, Al-Qur'an dan Terjemahannya ..., hal. 274.

$$
\text { والاخاء الذين كانوا يبوارثون بمما اولاً72 }
$$

(Zawil arham) dinukilkan dari Ibnu Abbas, Mujahid, 'Tkrimah, AlHasan, Qatadah, dan ulama lainnya mereka mengatakan bahwa ayat ini menasakhkan kewarisan dengan jalan perjanjian dan persaudaraan sesama kaum muslimin yang menjadi dasar kewarisan diantara mereka pada masa awal-awal Islam.

Imam Al-Jashash al-Hanafi didalam Ahkam Alquran mengatakan ayat ini menjadi hujjah untuk menetapkan kewarisan zawil arham yang tidak ditentukan hak mereka dalam harta warisan tidak pula ashabah. ${ }^{73}$ Ayat ini menetapkan hak kewarisan untuk kerabat zawil arham jika pewaris tidak meninggalkan ahli waris ashabul furudh ataupun ashabah. Ayat ini menunjukkan bahwa zawil arham lebih berhak untuk mendapatkan harta warisan sebab pada karabat zawil arham terdapat dua sebab kewarisan dibandingkan dengan baitul mal, yang mana baitul mal dengan orang yang meninggal dunia hanya mempunyai satu hubungan yaitu agama Islam, sedangkan zawil arham dengan orang meninggal dunia mempunyai dua hubungan yaitu agama Islam dan kekerabatan (nasab). Akan halnya mazhab Hanafiyah mempersamakan warisan dengan kekuasaan, mereka mengatakan bahwa oleh karena kekuasaan

${ }^{72}$ Wahbah az-Zuhaili, Tafsir Al-Munir, Jilid V. (Damaskus: Dar al-Fikr, 2009), hal. 434.

${ }^{73} \mathrm{Al}-J a s h a s h$ al-Hanafi, Ahkam Alquran, Jilid III, ( Beirut: Dar al-Kitab al-Abadi, t,t), hal.76.

137 | Hak Kewarisan Zawil Arham (Perspektif Mazhab Hanafiyah Dan Syafi'iyah) 
menyiapkan jenazah, menyalatkan, dan menguburkannya ada di tangan zawil arham, manakala para pewaris yang mempunyai bagian tertentu dan ashabah tidak ada, maka kekuasaan mawaris itu seharusnya ada pada zawil arham. ${ }^{74}$

Makna yang mendasar dari dalil ini ialah bahwa Allah SWT telah menyatakan atau bahkan menegaskan dalam kitab-Nya bahwa para kerabat lebih berhak untuk mendapatkan atau menerima hak waris dari pada yang lain. Di sini, lafazhal-arham yang berarti kerabat adalah umum, termasuk ashabul furudh, ashabah, serta selain keduanya. Jadi, makna kata al-arham mencakup kerabat yang mempunyai hubungan rahim, atau lebih umumnya hubungan darah. ${ }^{75}$

Ayat tersebut seolah-olah menyatakan bahwa yang disebut kerabat siapapun mereka, baik ashabul furudh, para ashabah, atau selain dari keduanya merekalah yang lebih berhak untuk menerima hak waris dari pada yang bukan kerabat. Bila pewaris mempunyai kerabat dan kebetulan ia meninggalkan harta waris, maka berikanlah harta waris itu kepada kerabatnya dan janganlah mendahulukan yang lain. Jadi, atas dasar inilah maka para kerabat pewaris lebih berhak untuk menerima hak waris dari

${ }^{74}$ Ibnu Rusyd, Bidayatul Mujtahid, Terj, Imam Ghozali Said, Zaidun, (Jakarta: Pustaka Amani, 1995), hal. 21.

${ }^{75}$ Beni Ahmad Saebani, Fiqh Mawaris..., hal. 185 . pada baitul mal. ${ }^{76}$

Hal ini juga berdasarkan firman-Nya yang lain;

Bagi orang laki-laki ada hak bagian dari harta peninggalan ibubapa dan kerabatnya, dan bagi orang wanita ada hak bagian (pula) dari harta peninggalan ibubapa dan kerabatnya, baik sedikit atau banyak menurut bahagian yang telah ditetapkan. (QS. AnNisaa' 7). 77

Melalui ayat ini Allah SWT menyatakan bahwa kaum laki-laki dan wanita mempunyai hak untuk menerima warisan yang ditingalkan kerabatnya, baik sedikit maupun banyak. Seperti yang disepakati oleh jumhur ulama bahwa yang dimaksud dengan zawil arham adalah para kerabat. Dengan demikian mereka (zawil arham) berhak untuk menerima warisan. 78

Selain berdalil dengan ayat diatas, pendapat mazhab Hanafiyah juga berdalil dengan hadis Rasulullah, diantaranya:

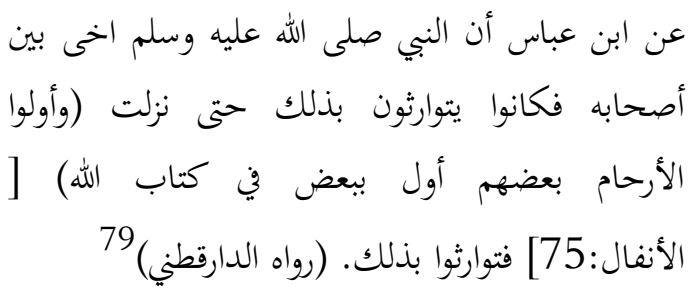

Dari Ibnu Abbas, bahwa Nabi SAW mempersaudarakan antara para sahabatnya, dan mereka saling mewarisi karena persaudaraan itu, hingga turun ayat, (orang-orang yang

${ }^{76}$ Ibid,. hal. 186

${ }^{77}$ Departemen Agama RI, Al-Qur'an dan Terjemahannya ..., hal. 116.

${ }^{78}$ Beni Ahmad Saebani, Fiqh Mawaris..., hal. 186.

${ }^{79}$ Asy-Syaukani, Nailul Authar, Terj, Amir Hamzah Fachridin, Jilid III, (Jakarta: PustakaAzzam, 2006), hal. 351. 
mempunyai hubungan kerabat itu sebagiannya lebih berhak terhadap sesamanya dari pada yang bukan kerabat di dalam kitab Allah) (AlAnfal: 75) lalu mereka mewarisi berdasarkan nasab.

$$
\begin{aligned}
& \text { عن المقداد بن معدي كرب عن النبي صلى الله عليه } \\
& \text { وسلم قال: من ترك مالا فلورثنه، وأنا وارث من لا وارث }
\end{aligned}
$$

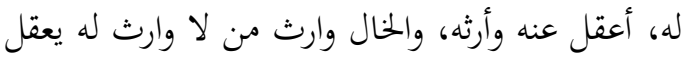

$$
\begin{aligned}
& \text { عنه ويرثه } 80
\end{aligned}
$$

Dari Al-Miqdam bin Ma'dikariba, Nabi SAW berkata: barang siapa yang meninggalkan harta maka harta tersebut untuk ahli warisnya, dan aku adalah ahli waris bagi yang tidak memiliki ahli waris, aku adalah orang yang membayarkan diyat dan mewarisinya, dan paman adalah ahli waris bagi orang yang tidak memiliki ahli waris dialah yang membayarkan diyat dan memberikan harta warisan. 81

$$
\begin{aligned}
& \text { عن أبي أمامة بن سهل: أن رجلا رمى رجلا بسهم }
\end{aligned}
$$

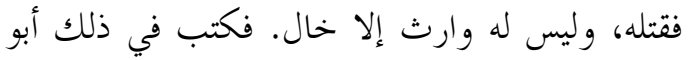

$$
\begin{aligned}
& \text { عبيدة بن الجراح إلى عمر، فكتب إليه عمر: أن النبي }
\end{aligned}
$$

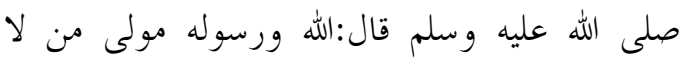

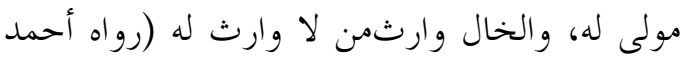

$$
\begin{aligned}
& \text { وابن ماجه) }
\end{aligned}
$$

Dari Abi Umamah bin Sahal: Bahwa seorang laki-laki melempar seorang laki-laki dengan anak panah sehingga membunuhnya, sedangkan orang yang terbunuh itu

${ }^{80}$ Ibnu Majah, Sunan Ibnu Majah, Jilid II, no hadis 2737, (Kairo: Dar al-Hadis, 1998), hal. 486 .

${ }^{81}$ Muhammad Nashiruddin Al-Albani, Shahih Sunan Ibnu Majah, Terj, Ahmad Taufiq Abdurrahman, Jilid II, (Jakarta: Pustaka Azzam, 2006), hal. 548.

82Ibnu Majah, Sunan Ibnu Majah, Jilid II, no hadis $2738 . .$. , hal.486. tidak mempunyai ahli waris selain pamannya (dari pihak ibu). Lalu abu Ubaidah bin Al-jarah menulis surat kepada Umar untuk menanyakan hal itu, maka Umar membalas: Sesungguhnya Nabi SAW telah bersabda, "Allah dan Rasul-Nya adalah maulanya orang yang tidask punya maula. Paman (dari pihak ibu) adalah pewaris bagi orang yang tidak mempunyai ahli waris." (Diriwayatkan oleh Ahmad dan Ibnu Majah). ${ }^{83}$

Menurut mazhab Hanafiyah jelas sekali dari ketiga hadis tersebut menunjukkan hak kewarisan untuk kerabat zawil arham apabila pewaris tidak meninggalkan kerabat ashabul furudh maupun ashabah, keponakan laki-laki dari saudara perempuan juga kerabat yang bukan dari ashabul furudh dan bukan pula termasuk ashabah. Pemberian Rasulullah SAW terhadap hak waris kepada zawil arham menunjukkan dengan tegas dan pasti bahwa para kerabat berhak menerima harta waris bila ternyata pewaris tidak mempunyai kerabat ashabul furudh yang berhak untuk menerimanya atau para ashabah.

Jadi dari dalil-dalil yng digunakan diatas, maka dapat diketahui bahwa metode istinbath hukum yang digunakan oleh mazhab Hanafiyah dalam hal ini, yaitu Alquran Surat Al-Anfal ayat 75, dan hadis Nabi.

2. Metode Istinbath hukum mazhab Syafi'iyah tentang hak kewarisan zawil arham

\footnotetext{
${ }^{83} \mathrm{Al}-$ Imam Asy-Syaukani, Ringkasan
} Nailul Authar..., hal. 349-350.

139 | Hak Kewarisan Zawil Arham (Perspektif Mazhab Hanafiyah Dan Syafi'iyah) 


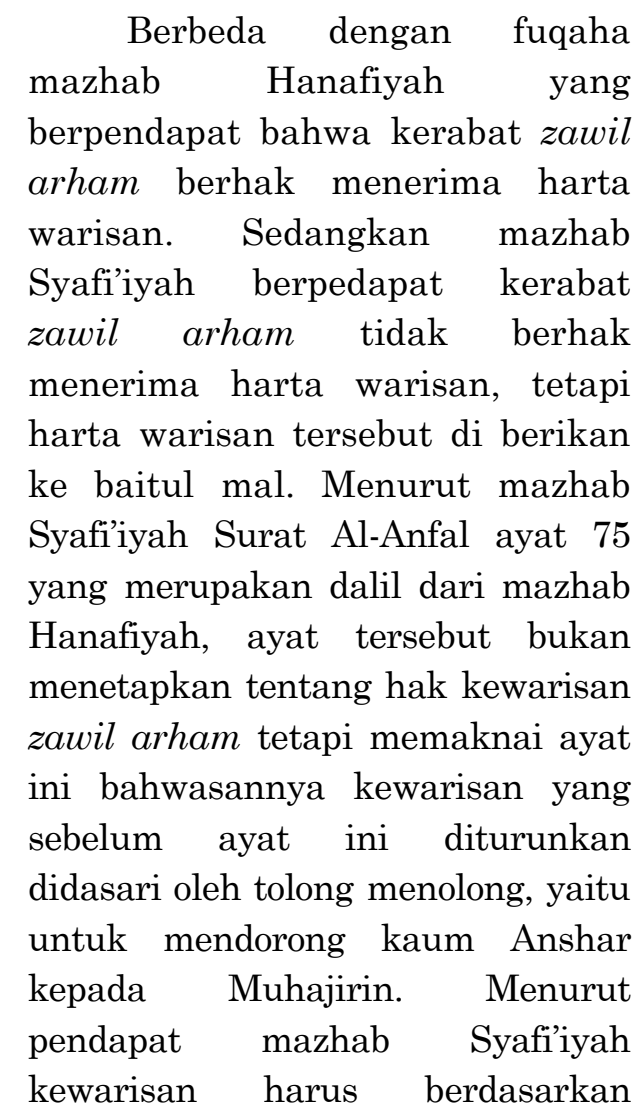
adanya sebab kekerabatan antara pewaris dan ahli waris, seperti halnya yang dijelaskan didalam tafsir Al-Munir, maksud dari katadalam Surat Al-Anfal ayat 75 ialah saham-saham (ketentuan bagian) yang telah Allah sebutkan dalam ayat-ayat mawarits pada Surat An-Nisa', jadi hanya kerabat yang telah ditentikan bagiannya saja yang berhak mendapat harta warisan. Oleh karena itu tidak ada hak warisan untuk kerabat zawil arham. ${ }^{84}$ Seandainya mereka memiliki hak maka Allah pasti menjelaskannya, ketiadaan penjelasan hak warian dan ketentuan besar kecilnya

${ }^{84}$ Wahbah az-Zuhaili, Tafsir Al-Munir..., hal. 434 . penerimaan zawil arham, bukanlah suatu kelupaan Allah. Sebab Allah tidak pernah lupa sama sekali, berdasarkan firman-Nya:

"... dan tidaklah Tuhanmu lupa." 85 (QS. Maryam: 64)

Dan mazhab Syafi'iyah berdalil dengan sebuah hadis yang diriwayatkan oleh 'Atha' bin Yasar:

$$
\begin{aligned}
& \text { عن عطاء بن يسار أن رجلا من الأنصارجاء إلى رسول }
\end{aligned}
$$

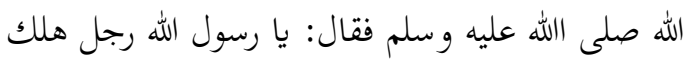

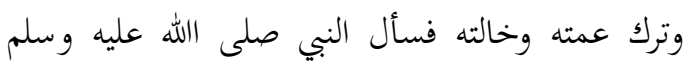

$$
\begin{aligned}
& \text { ذلك ثلاث مراث ثم قال: لا شيء لهم. }
\end{aligned}
$$

Dari 'Atha' bin Yasar, seorang lakilaki dari Anshar datang kepada Nabi SAW wahai Rasulullah, seorang laki-laki meninggal, meninggalkan 'ammah dan khalah, kemudian ia bertanya pada Rasul yang demikian itu tiga kali. Kemudian Nabi berkata: mereka tidak dapat. 86

Menurut mazhab Syafi'iyah 'ammah dan khalah didalam hadis tersebut tidak mendapatkan harta warisan karena mereka termasuk kedalam golongan zawil arham, sangat jelas betapa dekatnya kekerabatan 'ammah dan khalah dibandingkan dengan kerabat lainnya. Dengan demikian, jika keduanya tidak berhak menerima harta waris, kerabat lain pun tidak berhak menerimanya. 87

Setelah penulis meneliti, penulis tidak menemukan dalildalil yang digunakan murid Imam Syafi'i yaitu Al-Muzani, Ibnu Suraij dan An-Nawawi, mereka

\footnotetext{
${ }^{85}$ Departemen Agama, Alquran dan Terjemahan..., hal. 247.

${ }^{86}$ Fatchur Rahman, Ilmu Waris.., hal. 353

${ }^{87}$ As-Sayid al-Bakri, 'Ianatut thalibin, Jilid III, (Beirut: Dar Kitab Alawiyah), hal. 225.
} 
dalam menetapkan hak waris zawil arham, hanya saja Imam Nawawi mengatakan dalam kitabnya, karena rusaknya baitu mal maka dari itu kerabat zawil arham lebih berhak menerima warisan tersebut. 88 Dari uraian dalil diatas, dapat diketahui bahwa, metode istinbath hukum yang digunakan oleh mazhab Syafi'iyah terkait pendapatnya tentang hak kewarisan zawil arham, yang pertama adalah Alquran Surat Maryam ayat 64 dan hadis.

Setelah dicoba analisis lebih dalam dan ternyata sebab terjadinya perbedaan pendapat antara mazhab Hanafiyah dan mazhab Syafi'iyah. Disebabkan para fuqaha dari kedua mazhab tersebut berbeda dalam metode istinbath hukum yang mereka gunakan dalam menetapkan hak kewarisan zawil arham.

Adapun hadis yang dijadikan istinbath hukum kedua mazhab tersebut, penulis akan melihat kualitas kehujjahan hadis yang digunakan kedua mazhab, seperti hadis yang digunakan oleh mazhab Hanafiyah dari Al-Miqdam bin Ma'di bahwa hadis ini shahih, ia mempunyai dua sanad. Pertama, riwayat Ahmad, Sa'id bin Manhsur, Abu Daud, Ibnu Majah, Ibnu Hibban, dan Al-Hakim, semua dari Budail bin Maisarah dari Ali bin Abi Thalhah dengan sanad hasan. Kedua, riwayat Abu Daud, Al-Baihaqi dari Sahih bin Yahya bin Al-Miqdam dari ayahnya dari kakeknya dengan sanad dha'if. Abu Zur'ah Ar-Razi telah menilai hadis ini sebagai hadis hasan. Al-Albani menilai

${ }^{88}$ An-Nawawi, Yahya bin Syarf, Raudhah ath-Thalibin, Jilid VI..., hal. 7-8. hadis ini shahih. ${ }^{89}$ Jadi menurut penulis tanpa diragukan lagi hadis tersebut dapat di jadikan hujjah karena memiliki beberapa sanad, juga karena adanya beberapa riwayat pendukung hadis tersebut. Hadis pendukungnya seperti hadis dari Abu Umamah bin Sahal, menurut At-Tirmizi hadis ini adalah hadis hasan, ia termasuk hadis pendukung hadis sebelumnya, jadi bisa disimpulkan bahwa sanad terbaik dalam masalah ini adalah hadis Abu Umamah bin Sahal tersebut, hadis itu mempunyai sejumlah riwayat pendukung, Ibnu Hibban juga menilai hadis ini hadis shahih.

Adapun hadis yang digunakan untuk istinbat hukum oleh mazhab Syafi'iyah yaitu hadis dari 'Atha' bin Yasar, setelah penulis meneliti hadis tersebut, penulis tidak menemukan sanad lain yang dapat mendukung hadis tersebut. Penulis ingin mentarjih kedua dalil yang digunakan kedua mazhab tersebut. Pertama dari segi sanad, tarjih dari sisi ini dilakukan antara lain dengan melihat rawi yang menurut jumhur ulama ushul fiqh, hadis yang diriwayatkan oleh perawi yang lebih banyak jumlahnya, didahulukan dari pada hadis yang lebih sedikit perawinya. Kedua tarjih dari segi adanya faktor luar yang mendukung salah satu dari dua dalil yang bertentangan, dalil yang didukung oleh dalil yang lain termasuk dalil yang merupakan hasil ijtihad, didahulukan atas dalil yang tidak mendapat dukungan. Jadi menurut penulis dalil yang digunakan mazhab Hanafiyah lebih kuat dan

${ }^{89}$ Abdullah bin Abdurrahman Al-Bassam, Syarah Bulughul Maram, Terj. Thahirin Suparta, Jilid VI, (Jakarta: Pustaka Azzam, 2006), hal. 201.

141 | Hak Kewarisan Zawil Arham (Perspektif Mazhab Hanafiyah Dan Syafi'iyah) 
didahulukan, dikarenakan jumlah perawinya lebih banyak dan terdapat dalil pendukung hadis tesebut.

Sebelumnya penulis juga ingin melihat kembali dari kata arham dalam kata zawil arham merupakan bentuk jamak dari kata rahmun, yang berarti tempat pembentukan atau menyimpan janin dalam perut ibu. Kemudian artinya dikembangkan menjadi kerabat, baik datangnya dari pihak ayah ataupun dari pihak ibu. Pengertian ini tentu saja disandarkan karena adanya rahim yang menyatukan asal mereka, dengan demikian lafazh rahim tersebut umum digunakan dengan makna kerabat, baik dalam bahasa Arab ataupun dalam istiah syariat Islam. ${ }^{90}$ Allah berfirman didalam Surat An-Nisa' ayat 1 ialah:

Artinya; Hai sekalian manusia, bertakwalah kepada Tuhan-mu yang telah menciptakan kamu dari seorang diri, dan dari padanya Allah menciptakan isterinya; dan dari pada keduanya Allah memperkembang biakkan laki-laki dan perempuan yang banyak. dan bertakwalah kepada Allah yang dengan (mempergunakan) namaNya kamu saling meminta satu sama lain, dan (peliharalah) hubungan silaturrahim. Sesungguhnya Allah selalu menjaga dan mengawasi kamu. ${ }^{91}$

Kalimat wal arham dalam Surat An-Nisa' ayat 1 tersebut mengandung arti hubungan kerabat atau silaturahim. Makna keseluruhan dari ayat tersebut yaitu bahwa Allah SWT memerintahkan untuk selalu menjaga hubungan silaturahim

${ }^{90}$ Dian Khairul Umam, Fiqh Mawaris, (Bandung: Pustaka setia, 2006), hal. 97.

${ }^{91}$ Departemen Agama, Al-Qur'an dan Terjemahannya..., hal. 114. diantara sesama kerabat dalam segala hal. Kata al-arham itu kemudian dijadikan dasar dalam hal pembagian warisan bagi kerabat yang masih memiliki hubungan darah dengan pewaris, meskipun bukan saudara kandung. Demikian juga firman Allah:

Artinya: Dan orang-orang yang beriman sesudah itu kemudian berhijrah serta berjihad bersamamu Maka orang-orang itu Termasuk golonganmu (juga). orang-orangyang mempunyai hubungan Kerabat itu sebagiannya lebih berhak terhadap sesamanya (daripada yang bukan kerabat) di dalam kitab Allah. Sesungguhnya Allah Maha mengetahui segala sesuatu. ${ }^{92}$

Penulis melihat bahwa Asbabun Nuzul ayat ini, maka yang paling berhak menjadi pewaris seseorang adalah keluarga dan kerabat dekatnya. Maksudnya yang Jadi dasar waris mewarisi dalam Islam ialah hubungan kerabat, bukan hubungan persaudaraan keagamaan sebagaimana yang terjadi antara muhajirin dan anshar pada permulaan Islam. 93

Didalam firman-Nya juga:

Bagi orang laki-laki ada hak bagian dari harta peninggalan ibubapak dan kerabatnya,

Menurut penulis yang dimaksud dengan kata al-aqrabun (kaum kerabat) disini adalah kerabat zawil arham. Jadi hak waris pada kerabat itu adalah mutlak dan bersifat umum, tidak terbatas kepada kerabat golongan ashabul furudh dan ashabah saja. Tetapi juga kerabat zawil arham, dengan demikian hak waris seluruh kerabat itu harus

\footnotetext{
${ }^{92}$ Ibid., hal. 149

${ }^{93}$ Imam As-Suyuthi, Asbabun Nuzul, Terj. Muh Miftahul Huda, (Solo: Insan Kamil, 2016), hal. 299.
} 
berlandasan suatu ketentuan yang bersifat umum, yang dalam hal ini sudah tercakup pada kalimat alarham. Mengambil suatu ketentuan hukum dari suatu nash hendaklah bersumber dari pengertian umum yang terkandung dalam lafaz nash itu sendiri, bukan dari motif-motif yang khusus, sesuai dengan kaidah ushuliyah yang berbunyi:

$$
\text { العبرة بعموم الفظ لا بخصوص السبب }
$$

Pengambilan suatu ibarat menurut keumuman lafazh, bukan menurut kekhususan sebab. ${ }^{94}$

Andaikata didalam ayat tesebut (Al-Anfal 75) terkandung sebab-sebab yang khusus, niscaya Allah menjelaskan, sekalipun penjelasannya ditemukan dalam firman-Nya ditempat yang lain, yang telah dijelaskan oleh Allah di dalam ayat-ayat mawaris. Mengenai kewarisan kerabat ashabul furudh dan ashabah, adalah bersifat khusus, yakni khusus karena adanya sebab ikatan zaujiyah, bunuwah, ubuwah, dan lain sebagainya. Hingga dengan demikian tinggallah warisan kerabat zawil arham yang masih dilukiskan secara umum dengan menggunakan istilah kekerabatan atau arham.

Dari uraian diatas, dapat dipahami bahwa orang-orang yang mempunyai hubungan kekerabatan dengan pewaris, selain kedua puluh lima orang ahli waris yang telah disebutkan didalam bab II, atau mereka yang tidak mempunyai bagaian tertentu didalam Alquran termasuk kelompok zawil arham, dan kelompok zawil arham tersebut berhak mendapatkan harta warisan, karena mereka termasuk

${ }^{94}$ Nazar Bakry, Fiqh dan Ushul Fiqh, (Jakarta: Raja Grafindo persada, 2003), hal. 204. kerabat ahli waris yang memiliki tali kekerabatan dengan pewaris. Karena itu mereka lebih diutamakan untuk menerima harta tersebut dari pada baitul mal.

Tetapi, berdasarkan dalildalil tersebut mazhab Syafi'iyah tidak sependapat dengan mazhab Hanafiyah yang mengatakan kerabat zawil arham berhak menerima harta warisan. Menurut mazhab Syafi'iyah, asal pemberian hak waris adalah dengan adanya nash syar'i dan qath'i dari Alquran atau hadis. Dan dalam hal ini tidak ada satupun nash yang pasti dan kuat yang menyatakan wajibnya zawil arham untuk mendapat warisan. Jadi jika kita memberikan hak waris kepada kerabat zawil arham berarti kita memberikan hak waris tanpa dilandasi dalil yang pasti dan kuat. Hal seperti ini menurut syariah adalah batil, ini menurut mazhab Syafi'iyah.

Setelah penulis bandingkan
kedua pendapat mazhab Hanafiyah dan Syafi'iyah, penulis simpulkan bahwa kerabat zawil arham lebih berhak mendapatkan harta warisan dari pada yang lain, sebab mereka mempunyai hubungan kekerabatan dengan pewaris, tepatnya mereka sesama kerabat saling mewarisi. Disamping itu dalil yang mereka kemukakan lebih kuat dan akurat, karena merupakan pendapat mayoritas sahabat, tabi'in dan Imam Mujtahidin. Bahkan banyak ulama dari mazhab Maliki dan Syafi'i merujuk pada pendapat ini padahal dua imam mereka berpendapat sebaliknya. Jadi menurut penulis zawil arham termasuk kerabat dan kerabat itu wajib disambung. Apalagi mereka memang mempunyai pertalian 
yang erat dengan pewaris yaitu kekerabatan dan pertalian atas dasar Islam. Berbeda dengan prinsip yang diatur dalam baitul mal, karena bagi pewaris tidak ada hubungan apapun dengan baitul mal kecuali hubungan atas dasar Islam.

\section{PENUTUP}

Hak kewarisan zawil arham perspektif mazhab Hanafiyah dan mazhab Syafi'iyah pendapat yang dikemukakan secara garis besar diantaranya yaitu: Pendapat pertama yaitu mazhab Hanafiyah menyatakan bahwa zawil arham berhak menerima warisan apabila sudah tidak ada ahli waris dari golongan zawil furudh dan ashabah. Karena zawil arham lebih berhak menerima harta warisan dari pada yang lain, sebab mereka mempunyai hubungan kerabat dengan pewaris, dan mereka didahulukan daripada baitul mal. Pendapat kedua oleh Mazhab Syafi'iyah juga terdapat perbedaan antara Imam Syafi'i dan sebahagian murid-murid beliau. Imam Syafi'i menyatakan bahwa zawil arham tidak berhak mendapatkan harta warisan dari pewaris dengan alasan bahwa zawil arham bukan termasuk zawil furudh dan ashabah. Karena jika zawil furudh dan ashabah tidak ada, maka konsekuensinya harta peninggalan tersebut diserahkan ke baitul mal, karena jika diserahkan ke baitul mal akan mewujudkan kemaslahatan umum, sebab umat islam akan ikut merasakan kegunaannya. Sedangkan murid beliau seperti Al-Muzani, Ibnu Suraij dan AnNawawi berpendapat hak waris tersebut diberikan kekerabat zawil arham, karena menurut mereka baitul mal tidak lagi menjalankan dengan benar kegunaan baitul mal tersebut. Dalam menetapkan hukum yang terkait hak kewarisan zawil arham, mazhab Hanafiyah menggunakan dalil berdasarkan firman Allah Ta'ala Surat Al-Anfal ayat 75, dan hadis Rasulullah SAW. Sedangkan mazhab Syafi'iyah menggunakan dalil berdasarkan Surat Maryam ayat 64 dan hadis. 


\section{DAFTAR PUSTAKA}

Abdullah bin Abdurrahman Al-Bassam, Syarah Bulughul Maram, Terj. Thahirin Suparta, Jilid VI, (Jakarta: Pustaka Azzam, 2006)

Al-Baghawi, At-Tahzib Fi Fiqh Al-Imam Ash-Syafi'i, Jilid (Beirut: Dar al-Kutub al Ilmiyah, 1997)

Al-Ghamimi, al-Hanafi, Al-Lubab, Jilid IV, (Beirut: Maktabah Al-Ilmiyah)

Ali Parman, Kewarisan Dalam Al-Qur'an, (Jakarta: Raja Grafindo Persada, 1995)

Al-Jashash al-Hanafi, Ahkam Alquran, Jilid III, (Beirut: Dar al-Kitab al-'Abadi, t,t)

Amir Syarifuddin, Ushul Fiqh, Jilid I, (Jakarta: Kencana, 2008)

An-Nawawi, Yahya bin Syarf, Raudhah ath-Thalibin, Jilid VI, (Beirut: Dar Al-Kitab Al-'Ilmiyah, 1992)

As-Sayid al-Bakri, 'Ianatut thalibin, Jilid III, (Beirut: Dar Kitab Alawiyah)

Asy-Syaukani, Nailul Authar, Terj, Amir Hamzah Fachridin, Jilid III, (Jakarta: PustakaAzzam, 2006)

Ath-Thuri al-Qadiri al-Hanafi, Takhmilah Al-bahru Ar-Raiq, Jilid IX, (Kairo: Dar AlKitab Al-Islami, t.t)

Beni Ahmad Saebani, Fiqh Mawaris, (Bandung: Pustaka Setia, 2006)

Fatchur Rahman, Ilmu Waris, (Bandung: Alma'arif, 1975)

Ibnu Majah, Sunan Ibnu Majah, Jilid II, no hadis 2737, (Kairo: Dar al-Hadis, 1998)

Ibnu Rusyd, Bidayatul Mujtahid, Terj, Imam Ghozali Said, Zaidun, (Jakarta: Pustaka Amani, 1995)

Imam As-Suyuthi, Asbabun Nuzul, Terj. Muh Miftahul Huda, (Solo: Insan Kamil, 2016)

Muhammad Ali Ash-Syabuni, Pembagian Waris Menurut Islam, Terj: A. M. Basalamah, (Jakarta: Gema Insani Press, 2007)

Muhammad Nashiruddin Al-Albani, Shahih Sunan Ibnu Majah, Terj, Ahmad Taufiq Abdurrahman, Jilid II, (Jakarta: Pustaka Azzam, 2006)

Muhammad Suhaili Sufyan, Fiqh Mawaris Praktis, (Bandung: Citapustaka Media Perintis, 2012)

Nazar Bakry, Fiqh dan Ushul Fiqh, (Jakarta: Raja Grafindo persada, 2003)

Wahbah Az-Zuhaili, Figh Islam Wa Adillatuhu, Jilid XI, Terj: Abdul Hayyie aKattani, dkk, (Jakarta: Gema Insani, 2007)

Wahbah az-Zuhaili, Tafsir Al-Munir, Jilid V. (Damaskus: Dar al-Fikr, 2009)

Zainuddin al-Malibari, Fathul Mu’in, Jilid III, (Beirut: Dar Kitab Alawiyah). 